Pobrane z czasopisma Studia Bia?orutenistyczne http://bialorutenistyka.umcs.pl Data: 26/04/2023 16:49:10

DOI:10.17951/sb.2020.14.103-116

Studia Białorutenistyczne 14/2020

HISTORY, CULTURE AND SOCIOLOGY

ISSN: 1898-0457 e-ISSN: 2449-8270

Licence: CC BY 4.0

\title{
Olena Kondratiuk
}

\author{
State Scientific Centre of Cultural Heritage Protection from Technogenic Catastrophes (Ukraine) \\ Email: lenvin2007@gmail.com \\ ORCID: https://orcid.org/0000-0002-5996-1768
}

\section{Polesie: Frontier of Archaic Traditions (on the Example of Polish, Belarusian and Ukrainian Family Rituals)}

\begin{abstract}
Polesie: pogranicze archaicznych tradycji (na przykładzie polskiej, białoruskiej i ukraińskiej obrzędowości rodzinnej)

Палессе: памежжа архаічных традыцый (на прыкладзе польскай, беларускай і ўкраінскай сямейнай абраднасиі)
\end{abstract}

\begin{abstract}
Polesie remains the interest of ethnologists and anthropologists to this day since it has allowed us to record the rudiments of archaic rites including ones from the family cycle. Modern socio-humanitarianism gives preference to the study of certain realities in limited areas. Therefore, the theme concerning the reasons and ways of protecting children from premature death in Polesie is still relevant today. The goal of the author is to analyse the main reasons for these premature deaths and consider ways of protecting children from premature death; the role and significance of verbal formulas; subjects markers and home loci was used during this process. Object of the work research is the rituals of the family cycle as a component of folk culture of the inhabitants of Polesie. The subject of the research - magic ways to protect a baby. The methodological basis of work is in the principles of objectivity and historicism. Methods of comparative and structural-functional analysis were used to process field and archival, ethnographic and folklore material. The source base of the research consists of author's field materials and recordings of other scientists of the State Scientific Centre for Cultural Heritage Protection from Technogenic Catastrophes during complex historical-ethnographic expeditions within the territory of Polesie. Traditional ways of protecting a child were aimed at deceiving

* Financing: Funded from the budget of the Institute of Modern Languages and Literatures and the Institute of History of Maria Curie-Skłodowska University, from the funds of the Minister of Science and Higher Education for activities promoting science (contract no. 615/P-DUN/2019) and under the 'Support for Academic Journals' programme (contract no. 331/WCN/2019/1).

Publisher: Wydawnictwo UMCS
\end{abstract}


death via different rituals. Most of them were related to the choice of God parents, a name of a child, immitation of child purchase-sale, baby transfer through the window, burring of a child with a cradle, etc.

Keywords: child, death, baptized parents, window, cradle, Polesie

\begin{abstract}
Abstrakt
Polesie przyciąga obecnie uwagę etnologów i antropologów, gdyż wciąż pozwala na utrwalenie reliktów archaicznych obrzędów, w tym z cyklu życia rodzinnego. Nowoczesne podejście społeczno-humanistyczne oddaje przewagę badaniom konkretnych realiów w otaczającego człowieka świata w poszczególnych regionach. Autor artykułu podejmuje wciąż aktualną tematykę, która dotyczy przyczyn przedwczesnej śmierci w wieku dziecięcym i sposobów ochrony małoletnich przed nią w tradycyjnej kulturze ludowej na Polesiu. Celem pracy jest analiza przyczyn śmiertelności oraz podstawowych rytuałów magicznych związanych z ochroną dzieci przed przedwczesną śmiercią; analiza roli i znaczenia formuł słownych; analiza markerów przedmiotowych i „miejsc wspólnych” w tym procesie. Przedmiotem badań są obrzędy rodzinne jako składnik kultury ludowej mieszkańców Polesia. Podstawą metodologiczną pracy są zasady obiektywizmu i historyzmu. Do opracowania materiałów pochodzących z badań terenowych, archiwalnych, etnograficznych i folklorystycznych wykorzystano metody analizy porównawczej i strukturalno-funkcjonalnej. Bazę źródłową badań stanowią materiały zebrane w terenie przez autora oraz nagrania innych naukowców z Państwowego Naukowego Centrum Ochrony Dziedzictwa Kulturowego przed Katastrofami Technologicznymi, wykonanymi podczas kompleksowych wypraw historyczno-etnograficznych na terenie Polesia. Ludowe sposoby ochrony dziecka przed chorobą i śmiercią miały na celu jej „oszukanie” poprzez magiczne rytuały. Większość z nich wiąże się z wyborem rodziców chrzestnych, imieniem dziecka, imitacją kupna-sprzedaży dziecka, przeniesieniem dziecka przez okno, pochówkiem z kołyską itp.
\end{abstract}

Słowa kluczowe: dziecko, śmierć, rodzice chrzestni, okno, kołyska, Polesie

\begin{abstract}
Анатацыя
Палессе па сённяшні дзень прыцягвае ўвагу этнолагаў і антраполагаў, паколькі дагэтуль дазваляе фіксаваць рудыменты архаічных абрадаў, у тым ліку і з сямейнага цыкла. Сучасны сацыяльна-гуманітарны падыход аддае перавагу вывучэнню пэўных рэалій канкрэтных фрагментаў навакольнага свету ў канкрэтных рэгіёнах. Аўтар артыкула разглядае актуальную і сёння тэму, якая датычыць прычынаў заўчаснай смерці дзяцей i спосабаў абароны ад яе ў традыцыйнай народнай культуры на тэрыторыі Палесся. Мэтай працы з'яўляецца аналіз прычынаў смертнасці і асноўных магічных рытуалаў, звязаных з абаронай малалетніх ад заўчаснай смерці; аналіз ролі і значэння вербальных формулаў; аналіз прадметных маркераў і „агульных месцаў” у гэтым працэсе. Аб’ектам даследавання з'яўляюцца абрады сямейнага цыкла як кампанент народнай культуры жыхароў Палесся. Метадалагічнай асновай працы з'яўляюцца прынцыпы аб'ектыўнасці і гістарызму. Для апрацоўкі палявых, архіўных, этнаграфічных і фальклорных матэрыялаў
\end{abstract}


выкарыстоўваліся метады параўнальнага і структурна-функцыянальнага аналізаў. Базу даследавання складаюць уласныя палявыя матэрыялы аўтара, а таксама запісы іншых навукоўцаў Дзяржаўнага навуковага цэнтра аховы культурнай спадчыны ад тэхнагенных катастроф, зробленыя падчас комплексных гісторыка-этнаграфічных экспедыцый на тэрыторыі Палесся. Народныя спосабы аховы дзіцяці ад хвароб і смерці былі накіраваны на „падман” смерці з дапамогай магічных рытуалаў. Большасць з іх звязаны з выбарам хросных бацькоў, імем дзіцяці, імітацыяй куплі-продажу дзіцяці, пераносам немаўляці праз акно, пахаваннем з калыскай і г.д.

Ключавыя словы: дзіця, смерць, хросныя бацькі, акно, калыска, Палессе

$\mathrm{P}$ olesie, almost by the middle of the $20^{\text {th }}$ century, had preserved a significant layer of its archaic traditions, and in particular, family and calendar rituals. Using the illustrations of magic ways to protect a child from premature death, I will analyse their varieties and territorial distribution. For a person in a traditional society, the main aim of creating a new family was to continue his kind, that is, to give birth to a significant number of descendants. Childlessness or death of little children was considered a tragedy not only for particular members but for the whole family, because 'Адно дзіця - не дзіця, два дзіцяці - паў дзіця, тры дзіцяці - дзіця', ‘Де єдінец - то хай йому буде і конец'2, 'Biada bez dzieci, biada i z dziećmi'3 say folk proverbs of Poleshuks.

It was quite difficult for those families who did not have children to run a practically subsistence farming, so many rites in maternity, wedding and funeral rituals were aimed at successful procreation.

The questions of magic ways to protect a child from premature death were also covered in the works of Belarusian, Polish and Ukrainian scientists, in the context of research on the rites of the human life cycle, in particular: O. Kolberg, Natalia Gavriluk, N. Gavriluk, E. Boryak, T. Volodina, T. Varfalameeva, I. Makhovskaya, and others.

The aim of this article is to study the main magic methods of fighting early child mortality and determine their breadth of use in the territory of Polesie.

Reconstruction of Poleshuk's ideas about actions that should have prevented premature child mortality is impossible without a brief analysis of its causes. Researchers of folk culture at the beginning of the $20^{\text {th }}$ century drew attention to the fact that child mortality directly depended on the socio-economic situation of the peasants (lack of medical care, illness, difficult economic situation, etc.). Nevertheless, by the mid- $20^{\text {th }}$ century, the reasons that had magical connotations were more relevant for the local population: meeting of godparents carrying a child for baptism or a wedding procession

One child is not a child, two children are half a child, three children are a child.

When there is a single baby, then let it be the end.

Trouble without children, and trouble with children. 
with a funeral one the choice of the pregnant woman as godmother; the simultaneous baptism of several children in the Church; a midwife, if the first child, which she helped to be born, died, etc. But the main reason, in most cases, was considered to be the 'payment' of children for the sins of their grandfathers, great-grandfathers, or curses: 'Батьки таке зробили, шо діти мруть. Десь якусь біду зробили комусь. То діти мруть за гріхи батьків'4 (Materials-11, 2016, pp. 3). The most serious was considered 'women's' sins: termination or prevention of pregnancy, as well as infanticide (Kabakova, 2013, p. 174). By performing such actions, a woman disrupted the natural course of history and interfered with the sacred sphere of the universe, in which everything obeys the formula (seed-life-seed). Therefore, the atonement for such actions fell on the shoulders of the next few generations.

The traditional vision was followed by the Poleshchuks not only in determining the causes, but also in the ways of the elimination of the consequences, choosing appropriate methods of influence (prayers, quitrents, or ritual and magical actions). They were also guided by the principle that it was better to prevent a threat than to overcome its consequences. Therefore, from birth, a person's life was filled with actions of a magic nature, aimed at predicting and programming its fertility.

They began to think about the successful continuation of the family from the wedding day. The guests, presenting gifts to the newlyweds, with their wishes projected their fertility: 'Дарую синожать, шоб косили не докосили, да до року на родини просили'5 or 'Дарую сороку, шоб мали хлопца до року'6 (Materials-13, 2016, p. 12); 'Перапіваю вам уласны канапель, каб да году быў сын, як пень ${ }^{37}$ or 'Перапіваю вам стакан медзі, каб былі дзеці, як мядзведзі' ${ }^{\prime}$ (Novak, 2011, p. 101); 'Życzę więc Wam szczęścia wiele, Stadka dzieci, mrowia wnuków', 'Za ten bohaterski czyn, niechaj pierwszy będzie syn' ${ }^{10}$ (http://www.jakacards.pl/do_pobrania/, 2012). Such wishes can still be heard at modern Poleshchuk weddings.

For the same purpose, in Kiev, Chernigov and Gomel regions, on the third day of the wedding, millet or buckwheat porridge was cooked, which in Ukrainian Polesie was bought out by the bride's godfather, and in Belarusian Polesie - by one of the groom's brothers. In the end, they broke the pot, and the porridge was divided among the guests. These actions produced a meaning and were associated with the magic of procreation (Novak, 2011, p. 10, 210).

4 Parents did something [wrong], so children are dying. Somewhere they caused some trouble to someone. So, children died for the sins of their parents.

5 'Give you the hayfield for you mow and couldn't stop to mow and in a year invite us for the birth of a child'.

6 'Give you a magpie that a boy will be born in a year'.

7 'I drink and bring you my own hemp that within a year you have a son like a tree stump'.

8 'I drink and bring you a glass of copper so that you have children like bears'.

9 'I wish you a lot of happiness, a herd of children, and many grandchildren'.

10 'For this heroic deed, let the son be the first'. 
Молода першою набирала каші у фартух і обсівала нею двір, город, худобу. Потім по грудочці роздавали гостям. Цей обряд був покликаний сприяти родючості, як усього що є в господарстві так і самої молодої та їі гостей ${ }^{11}$ (Borisenko, 1988, p. 82).

Such verbal formulas-wishes and actions were somehow connected with the magic of fertility and aimed at programming successful motherhood.

It was the midwife who was first considered responsible for the fate and life of the child. In a dangerous moment of transition of a child into this world (birth), it was a good sign, 'to hail' the child: to call the boy by the name of the father (with the addition of «гу»: 'Гаврилогу, я тебе гукаю, одізвися божими трудами'12), and to call the girl by the mother's name. The method of using hails caused the effect of effective hailing (Borâk, 2009, p. 145).

According to popular beliefs, the child's name had a special meaning. Everywhere in Polesie it was believed that if in the family children 'are not bred' (die), the next baby should be named after the parents or after Adam and Eve - the first progenitors, or the name of a relative who had lived a long life, then the child will definitely live (Kolberg, 1890, p. 177).

No less important was the midwife's manipulation of the placenta, umbilical cord, and water after the baby's first bath. Their disposal had to take place in compliance with certain rules regarding the place and method of burial. Because any inaccuracies could lead to the death of all the children that this woman would give birth to: 'Бабі ж лічаць грыхом закопваць паслед уніз пупавінаю, думаючы, што гэтым яны здзяйсняць забойства будучых дзяцей, якія нарачоны гэтой жанчыне'13 (Seržputoǔskì, 2017, p. 136); ' ...odeszłe łożysko, t.z. miejsce, zakopuje babka w ziemię, pod chyżem domu, w sieni, lub komorze, sznurkiem do góry. Gdyby je porzuciła, nie byłoby to ze zdrowiem matki, gdyby zaś je zakopała sznurkiem na dół, położnica straciłaby 'swą płodność' ${ }^{14}$ (Biegeleisen, 1927, p. 62). Therefore, 'Baba' (midwife) clearly adhered to all the requirements during this process:

Місце бабушка закопувала пуд родючим деревом. Якшо пуд родючим то дитина буде рости, а якшо пуд таким, лозою чи шо то - нє. Мені бабушка казала: «Я закопала твоєї Наташки місце пуд яблуньку» $»^{15}$ (Materials-10, 2016, p. 11).

11 'The bride was the first to take porridge in an apron and sow it in the yard, garden, cattle. Then porridge was distributed by the handful to the guests. This rite was intended to promote fertility as well as everything that is on the farm, as well as the newlyweds themselves and their guests'.

12 'Havrylo-hu, I'm calling you, respond, God willing'.

13 'Midwives consider it a sin to bury the placenta with the umbilical cord down, thinking that by doing so they will commit the murder of future children who are destined for this woman'.

14 'The doula buries the departed placenta, a place, in the ground, under the house in the hall or chamber, with the umbilical cord up. If she threw it away, the mother would not have health, and if she buried it with the umbilical cord down, the woman in childbirth would lose her fertility'.

15 'Grandmother would bury the placenta under a fruitful tree. When under a fruitful tree, then the baby would grow, but when under an osier or a similar kind of that tree - then it would not. My grandmother told me: 'I buried your Natasha's placenta under the apple tree'. 
When the hole was dug in, the midwife said: 'Шоб усе родило і породиля іще дітей вродила' ${ }^{16}$ (Malinka, 1898, p. 263). For the same purpose, the midwife was pouring out water after the first bath of the baby 'лила пуд дерево плодове, шоб діти годувалиса, росли' ${ }^{17}$ (Materials-9, 2016, p. 4).

All these strategies were aimed at providing the child with a long and happy life. In the case when children continued to die in the family or the next desired pregnancy did not occur, 'Baba' performed non-standard actions with the placenta and the earth that covered it: in particular, they searched for the place where the placenta was buried, and moved the earth in it: ' 12 год не було дітей, то вирізали землю, перевернули место'18. According to the second version, when babies died, the ground from the place where the placenta was buried was scattered in the garden - 'щоб діти росли так, як трава на городі ${ }^{19}$. If this did not help, at the birth of the next child, the midwife, along with the placenta, buried a live rooster and a chicken, or two rag dolls - a boy and a girl - such 'sacrifices' were intended to ensure the normal growth of the child (Borâk, 2009, p. 171).

With the same motivation, they performed specific ritual actions in the context of the funeral rite. During the burial, together with the deceased child, the parents put certain items in the coffin, which were supposed to prevent further deaths of children in the family: 'у гроб де лежала дитина клали замка закритого та ключі, шоб за етою дитиною замкнуть, шоб не вмирали ${ }^{20}$ (Materials-6, 2015, p. 18).

Also, in the context of the funeral rite, in Central and Western Ukrainian Polesie and further on in the territory of modern Poland, the custom to take out of the house or even to bury the frames, railings or even cradle in a child's grave is recorded. The last time this custom was observed in the 60-70s of the $20^{\text {th }}$ century (Falkowski, 1933, p. 3-5; Nagornûk, 2011, p. 107; Tolstaâ, 2004, p. 562). In the village of Serkhov of Manevichi district in Volyn region there is a record of this tradition:

3 люлькою дитинку разом закопували на могилицах. А другую шукають, люльку. А як у кого діти родятса, да не вмирають то в тих позичают люльку. Поки знов новую зроблять. А тую отдають назад, шоб вже діти більш не вмирали ${ }^{21}$ (Materials-12, 2016, p. 21).

In both cases, the purpose of the ritual was to break the chain of children's deaths. In addition, it was generally forbidden for a mother to go to the cemetery after her dead firstborn.

16 'May everything give birth, and may the new mother give birth to more children'.

17 'Poured under a fruit tree so that children could be feed and grow'.

18 'There were no children for 12 years, so they cut the ground, turned the place upside down'.

19 'So that the children would grow like grass in the garden'.

20 'A closed lock and keys were placed in the coffin where the baby lay to lock it down so that [other babies] would not die'.

21 'Together with the cradle, the baby used to be buried in the cemetery. And [parents] would look for another cradle. And they would borrow a cradle from those who have children who did not die. Until a new one is made. And that one is given back so that the children no longer die'. 
All these actions came down to one thing, by any means to avert death: to make a 'sacrifice' to it, to deceive by substituting an 'unhappy' thing for a 'happy' one. The same principle of substitution is observed in the custom of 'selling' the child to other parents, in cases where the father or mother was considered a source of misfortune:

Як діти мруть: одне помре, друге, то тоді треба шоб мати рідна другой, у якої і п’ять уродилося і всі живі, треба шоб їй свою дитину продала. Та шо дать, там якісь копейки,

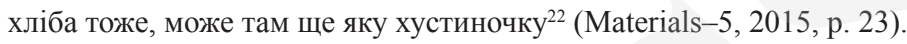

And those children knew, 'шо те їхні батьки. Вони головні, а ми вже другі батьки, а вони родні. Кажуть - батьку, мати'23 (Materials-6, 2015, p. 31). According to people tradition, it was not necessary to change so-called 'purchased' parents, since this could lead to misfortune:

Там одна у нас з Білорусії, купила дівочку з Делети, в сем'є дітей не було. Там одна

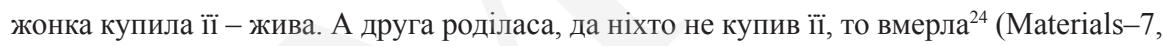
2015, p. 11).

Sometimes, the locus of the house was considered unlucky. In this case, the woman gave birth to a child in neighbors' house or in the house where 'children are fed':

В нас був такий випадок, шо жінка мала одно - вмерло, друге - вмерло, і вона поїхала до ворожилів, і вони їй сказали, шоби вона не родила в своїй хаті, а йшла до чужої хати родити і почали годуватися діти ${ }^{25}$ (Ganus, 2015, p. 96).

It was believed that this way death would not know about the new baby.

Manipulations with children's clothing were quite common in Polesie. From hanging the child's torn clothing (diapers or shirts) on roadside crosses (Rulikowski, 1879, p. 57), to purchasing clothes for the new baby by strangers: 'Моєй дачці да году его [husband's - О. К.] сестра адьожу покупала'26 (Materials-6, 2015, p. 14).

22 'When babies die: one dies, the other, then the mother need to find another woman who has perhaps five children and all are alive, to sell her child to her. And she needs to be given something, some pennies, bread too, maybe a handkerchief'.

23 'That those are their parents. They are the main ones, and we are the second parents, but they are relatives. They would say - father, mother'.

24 'There was one [lady] from Belarus, she bought a girl from Deleta, there were no children in the family. So, one woman bought her - she is alive. And the second girl was born, but no one bought her, so she died'.

25 'We had a case when a woman had the first baby - it died, the second one - died, so she went to the fortune-tellers, and they told her that she should not give birth in her house but should go to someone else's house to give birth there, and [since then] children were nursed [stayed alive]'.

26 'His [husband's - O. K.] sister bought clothes for my daughter until she was one year old. 
But most often Poleshuks changed godparents. After all, according to popular belief, after performing the rite of baptism, a special connection was established between them and the child. What is said in folk songs: 'Чи нещасна вродилася, / Чи зла доля судилася, / Чи такі куми брали - / Щастя-долі не вгадали'27. It was believed that godparents could become a guarantee of both a long and happy life for their godchildren and a quick death.

Оно в моєї жінки родяться діти. Ви христите з ким то, бах, померла дитина. Народилась друга - оп’ять же ж ви христите і друга померла. Ну так поговорили [parents - О. К.], давайте поміняєм [godparents - О. К.], а може від цього, може вони якіє грішниє ${ }^{28}$ (Materials-4, 2015, p. 18).

The change of the godparents with such motivation was known not only in Polesie, but also widely used by other Slavic nations (Gavrilûk, 1981, pp. 118-120; Tolstaâ, 2004, pp. 290-291; Tradycyjnâ̂ mastackaâ, 2012, p. 442).

There are several options for the changing of godparents in the researched area. It all depended on what criteria they were looking for in the 'new' godparents, such as those who would help the family attract the favour of fate: age, social or property status, blood relationship, and so on.

The most common was the motif of the so-called 'met godparents' (met, sent by God, the first ones they see, found or godparents from the road) - occasional people given by God (fate), whom the parents 'met' on the planned day. Their appearance made changes in the usual, traditional course of time and thus caused a change in the fate unfavourably disposed to the family (Tolstaâ, 2010, p. 290). Therefore, the first advice to such parents was: 'Don't take [godparents - O. K.] from home, but take who you meet” (Materials-14, 2016, p. 7); “Стрэчную куму бралі: вуйдзеш на вуліцу, каго стрэтіш - старую, малую - ужэ бяруць за куму'29 (Tradycyjnaâ mastackâิ, 2012, p. 442).

Several varieties of this custom have been recorded in Polesie. Most often, for the next child, both the godmother and the godfather were changed. However, there were various forms of manifestation of this custom, which differed in certain structural elements. In the first case, only a person of the same sex as the deceased children was replaced with the first person they met:

27 'Whether the unfortunate girl was born, / Whether the evil destiny was predestined, / Whether such godparents were taken - / But fortunate destiny was not divine'.

28 'My wife would give birth to children. You baptize one with someone, boom, the baby is dead. The second baby is born - again you baptize [it], and the second one dies. Well, [parents - O. K.] would have a chat, let's change [godparents. - O. K.], maybe that's the reason, maybe they are some sinners'.

29 'An encountered godmother used to be taken: you should go outside, and whoever you meet - the old one, the little one - you should take her as a godmother'. 
В моєї матери було штири хлопчики вродились і не годувались, а дивчати я була i менша була - ми годувалиса. То вже матери стали раяти. Ти йди по дорозі, як маєш до хреста дитину нести, і кого стрінеш із чоловіків, його і бери. А куму нє [не міняли. - O. К.], бо хлопци ж вмирали ${ }^{30}$ (Materials-8, 2016, p. 22).

In the other, the met godparents were searched for even before the birth of a child:

Як ходить беремена, не сьогодні, завтра вродить. А ми кросна ткали, от такий там ціпок отпадає от кросен. Вже дотикаю, ціпок падає на землю, то тре вибігти, якшо діти не годуютса, на двір, і кого побачиш - чи молодого, чи старого, і вже того за кума взяти. Вже тоді діти годуютьса ${ }^{31}$ (Materials-10, 2016, p. 18);

Калі вот я радзіла перва і памерло, дак ужэ куму ету не бяруць. Яшчэ як бярэменна [ўжэ другім дзіцём], ідуць па вуліцы - і каго стрэціць: як старую - за бабу бярэ, а маладую - за куму 32 (Varfalameeva, 2017, p. 4).

The choice of 'met' godparents was widely known in Poland, where in parallel they could invite poor people from under the Church (Biegeleisen, 1927, p. 126).

Another way to win over an unfavourable fate and 'cheat' death was the presence of several children at the sacrament of baptism, one of whom was to become the recipient of the other: '.. діти тре хрестити, а вони в вас не годуюца, то беруть $\mathrm{i}$ хлопца, і дівчину, да й вони хрестять. Шоб діти хрестили'з3 (Materials-1, 2010, p. 16). Even better if they were related to each other as brother and sister: 'Як діты нэ годуюцца, бралі кумамі брата і сястру, шоб був брат з ріднюю сэстрою за кумэ ${ }^{34}$ (Varfalameeva, 2017, p. 54). Aside from the brother and sister, they also took an old man and old woman (Stolberg, 1887, p. 175). They were guided by the principle of neglecting the usual performance of the rite, which was also supposed to help deceive death.

30 'My mother had four boys born but they were not nursed (did not survive), and the girls - me and my younger sister - we were nursed. Then they began to advise my mother: when it is time to carry the child to the cross [to baptize], go along the road, and whoever you meet from among men, take him. But not the godmother [did not change her. - O. K.] because the boys were dying'.

31 'When [the wife] was pregnant and was about to give birth any day. And we were weaving on a handloom, and such a stick fell off the loom. I was already finishing weaving, the stick fell to the ground. So, if the children are not nursed, you should run outside, and whoever you see - young or old, you take him as a godfather. Only then the children are nursed [stay alive]'.

32 'When I gave birth to the first child, and the baby died, the same godmother was no longer taken. While still pregnant [with the second child], I walked down the street and whoever I met, I took: an old woman - as a midwife, and a young woman - as a godmother'.

33 '.. you have to baptize babies, and they are not nursed [do not survive], then you take a boy and a girl, and they baptize. So, children have to baptize'.

34 'When children were not nursed [did not survive], [parents] would take a brother and sister as godparents, in order to have siblings as godparents'. 
Having found the 'right' godparents, who finally broke the chain of child mortality and brought happiness to the family, Poleshuks listened to the warning not to change them in future:

Якшо так буває, шо діти не годуються... так люди ідуть дорогою і стрічають кумів... Якшо ти його взяла і в тебе ше родяться діти, то всьо, ти не повинна його міняти. Ти повинна оп'ять його брати [as a godfather. - О. К.] ${ }^{35}$ (Materials-2, 2012, p. 9);

Мой батько був такий плохий, ніхто його за куми не брав. А була в батька сестра та вродилася дитинка [i взяла вона його за кума. - О. К.]... Да й та дитинка живе. А вродилася друга, взяли другі куми - вмерла, вродилася третя, взяли другі куми - вмерла, вродилася четверта. Та бабка, шо пупи зав'язувала, каже, бери ті самі куми! Ну вже знов мого батька і ту самую куму. I стала та дівчина жити ${ }^{36}$ (Materials-15, 2016, p. 43).

'I я ўсых астальніх дзяцей маць хросна' ${ }^{37}$ (Varfalameeva, 2017, p. 55). For Poleshuks, the question of the correct choice of godparents was especially significant, because according to popular beliefs, the future fate of the child, and sometimes life, depended on it.

Less well-known in Eastern Polesie and more common in Western Ukrainian, Belarusian and Polish Polesie was the custom that the godmother, who was a godmother in a family where children were 'not bred' passed them through the window:

Тут у адной у нас не гадаваліся, памірала. То, я як хрыссціла, дык передавала дзяцей праз вакно... як праз акно, то будуць. I я іх ва ўсё сваё учкручвала - у пялёнкі, адзяялца... ${ }^{38}$ (Varfalameeva, 2017, p. 55);

От як одно, друге, третє народица й вмирає. Тут вони беруть через окно передавають до хреста, шоб годувалиса ${ }^{39}$ (Materials, 2010, p. 13).

The motivation for such actions was one - to change the usual circumstances in order to break the chain of child mortality: '....не крозь двері, а крозь окно подавали,

35 'If it happens that children are not nursed... then people go along the road and meet godparents... If you take him [as a godfather] and you have more children, that's it, you should not change him. You have to take him again'.

36 'My father was so bad (sick), no one took him as a godfather. But my father had a sister, and she gave birth to a child [and she took him as a godfather. - O. K.]... And that baby lived. And the second [baby] was born, they took other godparents - [the baby] died; the third [baby] was born, they took other godparents - [the baby] died, then the fourth [baby] was born. And the old woman who tied cords said: take the same godparents! Well, again, my father and the same godmother. And that girl survived'.

37 'And I am the godmother of all the other children.'

38 'Here, one of us had [babies who] were not nursed, they died. So, when I baptized, I passed the babies through the window... if through the window, then they will live. And I wrapped them in all my things - in swaddling clothes, blankets...'

39 'One child, two, and three children are born and die. So, they take the child and pass through the window to the baptism so that the children grow up.' 
шоб через двері не йшли [do not die in infancy - O. К.]'40 (Materials-3, 2013, p. 17); 'dzieci wymierały, gdy je wynoszono drzwiami do chrztu, wybrano więc drogę przez okno'41 (Biegeleisen, 1927, p. 214).

Exploring birthing rites E. Boryak, notes that the window is especially important in the early infant's life when the door to the world is almost closed; this closing is compensated by the window - it is both a means of contemplation and control and, at the same time, - unregulated entrance into another world (Borâk, 2009, p. 253). Poleshuks believed that through the window there was contact of a person with the other world, ancestors, God. So, passing the baby through the window is creating a new road, respectively a concealment of the fact of the child's birth.

For the Ukrainian-Belarusian-Polish border area, the most common method of the struggle with premature infant mortality was to change the godparents based on various characteristics: age, gender, blood relationship, etc. Other methods: manipulations with the 'place', the umbilical cord, water after the first bath; burial of the frame, railing or cradle; passing the child through the window; and 'purchasing' the child had a more local character. However, all magic ways to protect a child from premature death involved deceiving death by performing rites different from the previous ones performed with the previously deceased child.

\section{Translated into English by Marharyta Svirydava and Esplanada Language Solutions}

\section{List of sources}

State Scientific Centre of Cultural Heritage Protection from Technogenic Catastrophes (Ukraine).

Materials recorded in the village of Kuhcha, Zarichnensky district of the Rovno region F.Zarichne - (VII-VIII) - 2010, st. un. (storage unit) N. Leshchenko, AF-D6. [Материалы, записанные в с. Кухче Заричненского р-на Ровенской обл. Ф. Заричне - (VII-VIII) 2010, Ед. хр. Н. Лещенко, АФ-Д6].

Materials-1, recorded in the village of Kukhotskaya Volya, Zarichnensky district of the Rovno region F. Zarichne - (VII-VIII) - 2010, st. un. N. Leshchenko, AF-D7. [Материалы-1, записанные в с. Кухотская Воля Заричненского р-на Ровенской обл. Ф. Заричне (VII-VIII) - 2010, Ед. хр. Н. Лещенко, АФ-Д7].

Materials-2, recorded in the village of Rechitsa, Ratnovsky, district of Volyn region F. KamenKashirsky - (VII-VIII) - 2012, st. un. N. Leshchenko, AF-D13. [Материалы-2,

\footnotetext{
40 '[we] passed [babies] not through the door, but through the window, so that they do not pass through the door.'

41 'Babies died when they were brought out by the door to baptism, so a way was chosen through the window.'
} 
записанные в с. Речица Ратновского р-на Волынской обл. Ф. Камень-Каширский (VII-VIII) - 2012, Ед. хр. Н. Лещенко, АФ-Д13].

Materials-3, recorded in the village of Belchaki, Bereznivsky district of the Rovno region F. Berezne - (VII-VIII) - 2013, st. un. O. Kondratyuk, AF-D12. [Материалы-3, записанные в с. Бельчаки Березнивского р-на Ровенской обл. Ф. Березне - (VII-VIII) - 2013, Ед. хр. О. Кондратюк, АФ-Д12].

Materials-4, recorded in the village of Derevok, Lyubeshovsky district, Volyn region. F. Lyubeshov - (VII-VIII) - 2015, st. un. O. Kondratyuk, AF-D14. [Материалы-4, записанные в с. Деревок Любешовского р-на Волынской обл. Ф. Любешов - (VIIVIII) - 2015, Ед. хр. О. Кондратюк, АФ-Д14].

Materials-5, recorded in the village of Milinovka, Brusilovsky district, Zhytomyr region from the migrants from the village of Deleta, Ovrutsky district, Zhytomyr region. F. Brusilov - (VIIIIX) - 2015, st. un. O. Kondratyuk, AF-D4. [Материалы-5, записанные в с. Милиновка Брусиловского р-на Житомирской обл. от переселенцев из с. Делета Овруцкого р-на Житомирской обл. Ф. Брусилов - (VIII-IX) - 2015, Ед. хр. О. Кондратюк, АФ-Д4].

Materials-6, recorded in the village of Zhovtnevo, Popelnyansky district, Zhytomyr region from the migrants from the village of Zarechka, Luginsky district, Zhytomyr region. F. Brusilov - (VIII-IX) - 2015, st. un. O. Kondratyuk, AF-D5. [Материалы-6, записанные в с. Жовтневе Попельнянского р-на Житомирской обл. от переселенцев из с. Заречка Лугинского р-на Житомирской обл. Ф. Брусилов - (VIII-IX) - 2015, Ед. хр. О. Кондратюк, АФ-Д5].

Materials-7, recorded in the village of Pylyponka, Brusilovsky district, Zhytomyr region from the migrants from Chervonosilka village, Ovrutsky district, Zhytomyr region. F. Brusilov - (VIIIIX) - 2015, st. un. O. Kondratyuk, AF-D6. [Материалы-7, записанные в с. Пилипонка Брусиловского р-на Житомирской обл. от переселенцев из с. Червоносилка Овруцкого p-на Житомирской обл. Ф. Брусилов - (VIII-IX) - 2015, Ед. хр. О. Кондратюк, АФ-Д6].

Materials-8, recorded in the village of Troyanovka, Manevitsky district, Volyn region. F. Manevichi - (VII-VIII) - 2016, st. un. O. Kondratyuk, AF-D2. [Материалы-8, записанные в с. Трояновка Маневицкого р-на Волынской обл. Ф. Маневичи - (VIIVIII) - 2016, Ед. хр. О. Кондратюк, АФ-Д2].

Materials-9, recorded in the village of Gradysk, Manevitsky district, Volyn region. Manevichi - (VII-VIII) - 2016, st. un. O. Kondratyuk, AF-D3. [Материалы-9, записанные в с. Градыськ Маневицкого р-на Волынской обл. Маневичи - (VII-VIII) - 2016, Ед. хр. О. Кондратюк, АФ-ДЗ].

Materials-10, recorded in the village of Lishnovka, Manevitsky district, Volyn region. F. Manevichi - (VII-VIII) - 2016, st. un. O. Kondratyuk, AF-D4. [Материалы-10, записанные в с. Лишновка Маневицкого р-на Волынской обл. Ф. Маневичи - (VII-VIII) - 2016, Ед. хр. О. Кондратюк, АФ-Д4].

Materials-11, recorded in the village of Stary Chortoryisk, Manevitsky district, Volyn region. F. Manevichi - (VII-VIII) - 2016, st. un. O. Kondratyuk, AF-D5. [Материалы-11, записанные в с. Старый Чорторыйск Маневицкого р-на Волынской обл. Ф. Маневичи - (VII-VIII) - 2016, Ед. хр. О. Кондратюк, АФ-Д5]. 
Materials-12, recorded in the village of Serkhov, Manevitsky district, Volyn region. F. Manevichi - (VII-VIII) - 2016, st. un. O. Kondratyuk, AF-D8. [Материалы-12, записанные в с. Серхов Маневицкого р-на Волынской обл. Ф. Маневичи - (VII-VIII) - 2016, Ед. хр. О. Кондратюк, АФ-Д8].

Materials-13, recorded in the village of Telchi, Manevitsky district, Volyn region. F. Manevichi - (VII-VIII) - 2016, st. un. O. Kondratyuk, AF-D9. [Материалы-13, записанные в с. Тельчи Маневицкого р-на Волынской обл. Ф. Маневичи - (VII-VIII) - 2016, Ед. хр. О. Кондратюк, АФ-Д9].

Materials-14, recorded in the village of Karasyn, Manevitsky district, Volyn region. F. Manevichi - (VII-VIII) - 2016, st. un. O. Kondratyuk, AF-D10. [Материалы-14, записанные в с. Карасын Маневицкого р-на Волынской обл. Ф. Маневичи - (VII-VIII) - 2016, Ед. хр. О. Кондратюк, АФ-Д10]

[Materials-15, recorded in the village of Godomichi, Manevitsky district, Volyn region. F. Manevichi - (VII-VIII) - 2016, st. un. O. Kondratyuk, AF-D13. [Материалы-15, записанные в с. Годомичи Маневицкого р-на Волынской обл. Ф. Маневичи - (VIIVIII) - 2016, Ед. хр. О. Кондратюк, АФ-Д13].

Życzenia ślubne. (2012). Taken from: http://www.jakacards.pl/do_pobrania/

\section{References}

Biegeleisen, Henryk. (1927). Matka $i$ dziecko $w$ obrzędach, wierzeniach $i$ zwyczajach ludu polskiego. Lwów: Drukarnia Antoniego Gojawiczyńskiego nakł. Towarzystwa Wydawniczego ,Ateneum”.

Borâk, Olena. (2009). Baba - povituha v kul'turno-istoričnij tradicï ukraïnciv: miž profannim i sakral'nim. Kiïv: İnstitut mistectvoznavstva, fol'kloristiki ta etnologiï ìm. M. T. Ril's'kogo NAN Ukraïni. [Боряк, Олена. (2009). Баба - повитуха в культурно-історичній традииї̈ україниів: між профанним і сакральним. Київ: Інститут мистецтвознавства, фольклористики та етнології ім. М. Т. Рильського НАН України].

Borisenko, Valentina. (1988). Vesil'nì zvičaï ta obrâdi na Ukrä̈nì: İstoriko-etnografične doslidžennâ. Kiïv: Naukova dumka. [Борисенко, Валентина. (1988). Весільні звичаї та обряди на Україні: Історико-етнографічне дослідження. Київ: Наукова думка].

Falkowski, Jan. (1879). Notatki etnograficzne z Polesia. Cmentarze. Lwów, the print from Wiadomości Ludoznawcze, 2(1-2) from 1933.

Ganus, Dzenislava. (2015). Ditina v sistemì narodnih vìruvan' ta obrâdìv naselennâ ukraïns'kopol's'kogo pograniččâ. Disertaciâ na zdobuttâ naukovogo stupenâ kandidata istoričnih nauk. Kiїv. [Ганус, Дзенислава. (2015). Дитина в системі народних вірувань та обрядів населення українсько-польського пограниччя. Дисертація на здобуття наукового ступеня кандидата історичних наук. Київ].

Gavrilûk, Nataliâ. (1981). Kartografirovanie duhovnoj kul'tury (po materialam rodil'noj obrâdnosti ukraincev). Kiev: Naukova dumka. [Гаврилюк, Наталия. (1981). Картографирование духовной культуры (по материалам родильной обрядности украинщев). Киев: Наукова думка]. 
Kabakova, Galina. (2013). Polìs'ka narodna antropologiâ: žìnočij tekst. In: O. Borâk, M. Maêrčik (eds.). Etnografiâ statevogo žittâ j tilesnosti: Zbirnik statej (pp. 173-194). Kï̈v: Centr kul'turno-antropologičnih studij, PAT «VÌPOL». [Кабакова, Галина. (2013). Поліська народна антропологія: жіночий текст. В: О. Боряк, М. Маєрчик (ред.). Етнографія статевого життя ци тілесності: Збірник статей (рp. 173-194). Київ: Центр культурно-антропологічних студій, ПАТ «ВІПОЛ»].

Kolberg, Oskar. (1887). Dzieła wszystkie. Vol. 26: Mazowsze, part 3. Kraków.

Kolberg, Oskar. (1890). Dzieła wszystkie. Vol. 33: Chetmskie, part 1. Kraków.

Malinka, A. (1898). Rodyny i hrestyny. Kievskâ̂ starina, 61(5). [Малинка, А. (1898). Родыны и хрестыны. Киевская старина, 61(5)].

Nagornûk, Oleksìj. (2011). Kartografuvannâ âviŝ pohoval'no-pominal'noï atributiki na mežì Zahìdnogo ì Seredn'ogo Polìssâ. Problemi etnomuzikologiï, 6, pp. 104-112. [Нагорнюк, Олексій. (2011). Картографування явищ поховально-поминальної атрибутики на межі Західного і Середнього Полісся. Проблеми етномузикологіï, 6, pp. 104-112].

Novak, V. S. (annex). (2011). Vâsel'nâ̂ tradycyâ Gomel'ščyny: fal'klorna-ètnagrafičny zbornik. Mìnsk: Prava ì èkanomika. [Новак, В. С. (укладанне). (2011). Вясельная традыцыля Гомельшчыны:: фальклорна-этнаграфічны зборнік). Мінск: Права і эканоміка].

Rulikowski, Edward. (1879). Zapiski etnograficzne z Ukrainy. Zbiór wiadomości do antropologii krajowej, 3(3), pp. 62-166.

Seržputoǔskì, Alâksandr. (2017). Palešuki - belarusy: ètnagrafičny. Narys, transl. from Rus. and comment. by Sârgeâ Gruntova; text preparation, ill. and the epilogue by Aleg Lylenka. Mìnsk: Belaruskaâ navuka. [Сержпутоўскі, Аляксандр. (2017). Палешукі - беларусьл: этнаграфічныл. Hapыс, пер. з рус. і камент. Сяргея Грунтова; падрыхтоўка тэксту, іл. і паслясл. Алега Лыленкі. Мінск: Беларуская навука].

Tolstaâ, Svetlana. (2004). Kolybel'. In: N. Tolstoj (ed.). Slavânskie drevnosti. Ėtnolingvističeskij slovar', Vol. 2. Moskva: „Meždunarodnye otnošeniâ”. [Толстая, Светлана. (2004). Колыбель. В: Н. Толстой (ред.). Славянские древности. Этнолингвистический словарь, Т. 2. Москва: „Международные отношения”].

Tolstaâ, Svetlana. (2010). Semantičeskie kategorii âzyka kul'tury: Očerki po slavânskoj ètnolingvistike. Moskva: Knižnyj dom «Librokom». [Толстая, Светлана. (2010). Семантические категории языка культуры: Очерки по славянской этнолингвистике. Москва: Книжный дом «Либроком»].

Tradycyjnaâ mastackaâ kul'tura belarusaǔ u 6 t. (2012). Vol. 6. Taccâna Valodzìna and others.; T. Varfalameeva (idea and general editing). Gomel'skae Palesse i Padnâproǔe. Book 1. Minsk: Vyšèjšaâ škola. [Традыц̨ыйная мастацкая культура беларусаў у 6 m. (2012). Book. 6. Таццяна Валодзіна і інш.; Т. Варфаламеева (ідэя і агул. рэдагаванне). Гомельскае Палессе і Падняпроуе. Кн. 1. Мінск: Вышэйшая школа].

Varfalameeva, Tat'âna. (2017). Sâmejnyâabradyìzvyčaì. Mìnsk: Vyšèjšaâškola. [Варфаламеева, Татьяна. (2017). Сямейныя абрады і звычаі. Мінск: Вышэйшая школа]. 